\title{
Exogenous hydrogen peroxide increases dry matter production, mineral content and level of osmotic solutes in young maize leaves and alleviates deleterious effects of copper stress
}

Sule Guzel ${ }^{1}$ and Rabiye Terzi ${ }^{2^{*}}$

\begin{abstract}
Background: The effects of exogenously applied $\mathrm{H}_{2} \mathrm{O}_{2}$ on growth, water status, the mineral ion content $\left(\mathrm{Na}^{+}, \mathrm{K}^{+}\right.$, $\mathrm{Ca}^{2+}, \mathrm{Mg}^{2+}$ and $\mathrm{Cu}^{2+}$ ), proline, total sugars and soluble proteins were assessed in leaves of maize (Zea mays L.) cultivars, Akpinar and Pegaso exposed to excess copper $(0.5 \mathrm{mM})$. Seedlings were grown in equal-sizes plastic pots and irrigated with Hoagland nutrient solution containing $\mathrm{H}_{2} \mathrm{O}_{2}$ or/and copper. Different treatments taken for pot experiments were named as the control $(\mathrm{C}), \mathrm{H}_{2} \mathrm{O}_{2}$ treatment only $\left(\mathrm{H}_{2} \mathrm{O}_{2}\right)$, excess $\mathrm{Cu}(\mathrm{Cu})$ and, $\mathrm{Cu}$ stress combined with $\mathrm{H}_{2} \mathrm{O}_{2}$ pretreatment $\left(\mathrm{Cu}+\mathrm{H}_{2} \mathrm{O}_{2}\right)$.

Results: Treatment of $\mathrm{H}_{2} \mathrm{O}_{2}$ caused the increases in growth, water content, mineral concentration, proline, total sugar and soluble protein contents compared to the control groups in the leaves of both cultivars. Yet excess copper caused reductions in the growth, leaf water potential, $\mathrm{Na}^{+}, \mathrm{K}^{+}, \mathrm{Ca}^{+}, \mathrm{Mg}^{2+}$ concentrations and soluble protein levels but increases in proline, total soluble sugars and $\mathrm{Cu}^{2+}$ contents compared to the control group. Dry matter, leaf water potential and mineral content of $\mathrm{Cu}+\mathrm{H}_{2} \mathrm{O}_{2}$ group revealed a lower decrease than $\mathrm{Cu}$ group ones. A higher increase was also observed in proline and total sugar contents of $\mathrm{Cu}+\mathrm{H}_{2} \mathrm{O}_{2}$ group than $\mathrm{Cu}$ group ones in both cultivars.

Conclusions: These data revealed that exogenous $\mathrm{H}_{2} \mathrm{O}_{2}$ might increase the dry matter production and the mineral ion distribution in maize seedlings. Moreover, osmotic regulation might be involved in alleviation of copper toxicity of maize leaves by pretreatment of $\mathrm{H}_{2} \mathrm{O}_{2}$.
\end{abstract}

Keywords: Copper toxicity; $\mathrm{H}_{2} \mathrm{O}_{2}$ treatment; Maize; Mineral uptake; Osmotic solute

\section{Background}

Modern human activities like mining, smelting, municipal waste disposal and electroplating are the important sources of heavy metal pollution in the environment. Among the heavy metals, copper $\left(\mathrm{Cu}^{2+}\right)$ is considered to be one of the most important pollutants of the air and is also very significant pollutant of agricultural soils (Alloway, 1990). Soils may contain elevated levels of $\mathrm{Cu}$ because of its widespread use as a pesticide, land application of sewage sludge as well as mining and smelting

\footnotetext{
* Correspondence: rabiaterzi@ktu.edu.tr

${ }^{2}$ Department of Biology, Faculty of Sciences, Karadeniz Technical University, Trabzon 61080, Turkey

Full list of author information is available at the end of the article
}

activities. However, $\mathrm{Cu}$ is essential micronutrient for normal plant metabolism and involved in a number of physiological processes such as photosynthesis, respiration, carbohydrate distribution and protein metabolism. On the other hand, even metabolic metals beyond a threshold concentration are harmful to biological systems (Foy et al., 1978). For instance, excess Cu might decrease the leaf water content, shoot elongation, plant biomass and germination rate (Ahsan et al., 2007).

Modulation of water content, biomass and osmotic solutes in plants after exposure to copper was frequently reported in the literature (e.g. Chen et al., 2001). Important among a variety of compatible osmolytes in higher plants were soluble sugars, organic acids, proline, soluble 
proteins (Ashraf, 2004) and inorganic minerals such as sodium, potassium, calcium and chlorine (Chen and Jiang, 2010). Sucrose content, one of soluble sugars increased in the cucumber leaves by copper stress and the uptake and the upward translocation of the ions were altered (Alaoui-Sosse et al., 2004). Similarly, proline content increased in plants when exposed to wide variety of environmental stresses and thus provided the plants protection against damage by reactive oxygen species (Aspinall and Paleg, 1981). For instance, excess copper induced accumulation of proline in various plants such as Oryza sativa (Chen et al., 2001) and Nicotiana benthamiana (Ku et al., 2012). Adversely, it has been shown a decrease in soluble protein level at several stress condition like copper and aluminum stresses (Yadav et al., 2009). Namely, both organic and inorganic solutes are essential for osmoregulation in plants, especially stress conditions. However, their relative contribution to osmotic adjustment varies from plant to plant or species to species, or even within different tissue of same plant (Ashraf, 2004). On the other hand, it has been well known that $\mathrm{H}_{2} \mathrm{O}_{2}$ is a major kind of reactive oxygen species in plant tissues. However, increasing lines of evidence supported the idea that $\mathrm{H}_{2} \mathrm{O}_{2}$ might act as a signal molecule with multiple functions in plants. Numerous studies have shown that the application of $\mathrm{H}_{2} \mathrm{O}_{2}$ at low concentrations could improve plant tolerance to heat stress (Gao et al., 2010), salt stress (De Azevedo Neto et al., 2005; $\mathrm{Li}$ et al. 2011), aluminum-induced oxidative stress (Xu et al., 2011) and heavy metal stress (Lin et al. 2004; Hu et al., 2009). The increased metal stress tolerance was attributed to induced antioxidant defense system after pretreatment with $\mathrm{H}_{2} \mathrm{O}_{2}$ in rice seedlings ( $\mathrm{Hu}$ et al., 2009). Despite a large number of reports detailing plant tolerance mechanisms to heavy metals, plant responses to $\mathrm{H}_{2} \mathrm{O}_{2}$ pretreatment under heavy metal toxicity are not properly understood.

It is known that crop plants, such as maize, wheat and barley may be subjected to heavy metal stress during their growing period. The accumulation of heavy metals in the seeds and other above ground parts of maize has been becoming a serious problem for agriculture and human health. Maize (Zea mays L.) is an important staple C4 food crop in many countries of the world and it accounts for around 712 million metric tones in 2006. Early studies showed that excess copper reduced plant biomass and cell increment of many plant species (Ouzounidou et al., 1998). As mentioned, application of $\mathrm{H}_{2} \mathrm{O}_{2}$ at low concentrations could induce stress tolerance in plants. However, the effect of $\mathrm{H}_{2} \mathrm{O}_{2}$ pretreatment to $\mathrm{Cu}$ toxicity is far from unclear. The objective of this study was to determine the response of $\mathrm{H}_{2} \mathrm{O}_{2}$ pretreatment to high copper content in two maize cultivars, Akpinar and Pegaso differently sensitive to water deficit. The biomass accumulation, alterations in water status, mineral ion content $\left(\mathrm{Na}^{+}, \mathrm{K}^{+}, \mathrm{Ca}^{2+} \mathrm{Mg}^{2+}\right.$ and $\left.\mathrm{Cu}^{2+}\right)$, soluble protein, proline and total soluble sugars were investigated in the leaves of two maize cultivars pretreated with $\mathrm{H}_{2} \mathrm{O}_{2}$ under $\mathrm{Cu}$ stress.

\section{Methods}

Plant material, growth and $\mathrm{H}_{2} \mathrm{O}_{2} / \mathrm{CuSO}_{4}$ treatment

Two Zea mays L. cultivars differently sensitive to water deficit (cv. Pegaso more tolerant than Akpinar cv.) were provided from Black Sea Agricultural Research Institute, Eskisehir, Turkey and Limagrain Seed Production Company, Istanbul, Turkey. Seeds were surface sterilized with $0.1 \% \mathrm{HgCl}_{2}$ for $3 \mathrm{~min}$ followed by repeated washings with sterilized distilled water. Seeds were sown in pots (14 $\mathrm{cm}$ height, $16 \mathrm{~cm}$ top and $11 \mathrm{~cm}$ bottom diameter) containing sterilize water washed sand. Seedlings were grown in a growth chamber with the following parameters: $16 \mathrm{~h}$ light and $8 \mathrm{~h}$ darkness at $25^{\circ} \mathrm{C} \pm 2$, relative humidity $60 \% \pm 5$, photon flux density of at the surface of the leaves $400 \mu \mathrm{mol} \mathrm{m} \mathrm{m}^{-2} \mathrm{~s}^{-1}$ and were watered once per two days with Hoagland nutrient solution ( $\mathrm{pH}$ 6.0). When the second leaves were fully expanded, the pots were divided into four groups for each maize cultivar. Two groups were watered with Hoagland nutrient solution, and the other two groups were watered with freshly prepared Hoagland nutrient solution containing $0.5 \mathrm{mM}$ $\mathrm{H}_{2} \mathrm{O}_{2}$. The $\mathrm{H}_{2} \mathrm{O}_{2}$-applied plants were watered with either the Hoagland nutrient solution only or Hoagland nutrient solution containing $0.5 \mathrm{mM} \mathrm{CuSO}_{4}$ for additional five days and were designated as " $\mathrm{H}_{2} \mathrm{O}_{2}$ treatment $\left(\mathrm{H}_{2} \mathrm{O}_{2}\right)$ ", and " $\mathrm{Cu}+\mathrm{H}_{2} \mathrm{O}_{2}$ pretreatment $\left(\mathrm{Cu}+\mathrm{H}_{2} \mathrm{O}_{2}\right)$ ", respectively. The other two groups of the pots were separately watered with either of the two types of nutrient solutions and were named "control (C)," and $\mathrm{Cu}$ stress $(\mathrm{Cu})$ ". After two days of the treatments, samples of the third leaf were used for the following analyses.

\section{Cu analysis}

Leaf samples were extensively washed with distilled water and then the samples were oven-dried and ground to power. The powder was ashen in a muffle furnace at $550^{\circ} \mathrm{C}$ for $4 \mathrm{~h}$ and the residue was brought to a standard volume with $1 \mathrm{M} \mathrm{HNO}_{3}$. Cu concentration of the extract was determined by a flame atomic absorbption spectrophotometer (Unicam, 929 AAS). The copper content of tissues was expressed as $\mu \mathrm{g} / \mathrm{g}$ dry weight.

\section{Determination of hydrogen peroxide content}

To determine endogenic $\mathrm{H}_{2} \mathrm{O}_{2}$ content after exogenous applications, hydrogen peroxide content was determined according to modified method of Velikova et al. (2000). Leaves $(0.25 \mathrm{~g})$ were ground in $3 \mathrm{ml}$ of $5 \%$ trichloroacetic acid with $0.1 \mathrm{~g}$ activated charcoal at $0^{\circ} \mathrm{C}$. To $0.5 \mathrm{ml}$ aliquot 
of the supernatant, $0.5 \mathrm{ml}$ of $10 \mathrm{mM}$ potassium phosphate buffer ( $\mathrm{pH} 7.0$ ) and $0.75 \mathrm{ml}$ of $1 \mathrm{M} \mathrm{KI}$ were added. The absorbance was measured at $390 \mathrm{~nm}$ and $\mathrm{H}_{2} \mathrm{O}_{2}$ content was expressed as $\mu \mathrm{mol} \mathrm{g}^{-1}$ fresh weight.

\section{Growth measurement}

To obtain enough data on variations in the growth of the plants, the measurement of dry weight, and the grade of growth inhibition (GGI) were recorded. To measure dry weight, the plants were harvested from four group pots and fresh weights of the leaves were determined. Then the samples were oven-dried at $80^{\circ} \mathrm{C}$ for 24 hours (Jiang et al., 2004). The grade of growth inhibition was also evaluated by using following formula according to Leita et al., 1993. All treatments were compared to the control group (control GGI $=0$, i.e., $100 \%$ growth).

Grade of Growth Inhibition (GGI) =

[(Dry weight of control plants-Dry weight of treated plants $) /($ Dry weight of control plants $)] \times 100$

\section{Measurement of water content}

Leaf water potential $\left(\Psi_{\text {leaf }}\right)$ was measured with a C52 thermocouple psychrometer (Wescor, Inc., Logan, UT, USA). Discs about $6 \mathrm{~mm}$ in diameter were cut from leaves and sealed in a C-52 psychrometer chamber. The readings were recorded by a Wescor PSYPRO water potential data logger in the psychrometric mode after samples were equilibrated for $45 \mathrm{~min}$. Values of leaf water potential were measured as $\mathrm{MPa}$.

Relative water content (RWC) of the leaves was estimated according to the method of Castillo (Castillo, 1996). Samples $(0.5 \mathrm{~g})$ were saturated in $100 \mathrm{ml}$ of distilled water for $24 \mathrm{~h}$ at $4^{\circ} \mathrm{C}$ in the dark and their turgid weights were recorded. Subsequently, they were dried at $65^{\circ} \mathrm{C}$ of oven for $48 \mathrm{~h}$ and their dry weights were recorded. RWC was calculated as given below:

$$
\operatorname{RWC}(\%)=[(\mathrm{FW}-\mathrm{DW}) /(\mathrm{TW}-\mathrm{DW})] \times 100
$$

where FW, DW, and TW are fresh weight, dry weight, and turgid weight, respectively.

\section{Determination of proline content}

Proline content was achieved according to the method Bates et al. (1973), and dried ground leaves (0.25 g) were used for proline extraction. Samples were homogenized in $5 \mathrm{ml} 3 \%$ sulfosalicylic acid and extracts were centrifuged at $8000 \times \mathrm{g}$ for $15 \mathrm{~min}$. $1 \mathrm{ml}$ filtrate was mixed with equal volumes of acetic acid and ninhydrin reagent $(1.25 \mathrm{~g}$ ninhydrin, $30 \mathrm{ml}$ of glacial acetic acid, $\left.20 \mathrm{ml} 6 \mathrm{M} \mathrm{H}_{3} \mathrm{PO}_{4}\right)$ and incubated for $1 \mathrm{~h}$ at $100^{\circ} \mathrm{C}$. The reaction was stopped by placing the test tubes in ice cold water. The samples were rigorously mixed with $3 \mathrm{ml}$ toluene. After $50 \mathrm{~min}$, the light absorption of the toluene phase was estimated at $520 \mathrm{~nm}$ on a UV-VIS spectrophotometer. The proline concentration was determined using a standard curve. Free proline content was expressed as $\mu \mathrm{g} / \mathrm{g}$ dry weight.

\section{Determination of soluble protein content}

For extraction of soluble proteins, the leaf samples were freshly harvested and fixed in liquid nitrogen. Thawed leaves were homogenized in $0.05 \mathrm{M}$ sodium phosphate buffer ( $\mathrm{pH}$ 6.0) with $0.1 \%$ polyvinylpolypyrrolidone (PVPP). The homogenate was filtered through cheesecloth. The filtered homogenate was centrifuged at $20000 \times g$ for $20 \mathrm{~min}$ at $4^{\circ} \mathrm{C}$. After centrifugation, the supernatant was taken and used for protein measurements. Soluble protein content was assayed according to Bradford (1976). Absorbance was read on a UV-VIS spectrophotometer at $595 \mathrm{~nm}$. The soluble protein concentration was determined by using bovine serum protein (BSA, Sigma, USA) as a standard and expressed as $\mathrm{mg} / \mathrm{g}$ fresh weight.

\section{Determination of total soluble sugar content}

Total soluble sugar content was determined by phenolsulfiric acid method (Dubois et al., 1956). Dry leaves $(0.1 \mathrm{~g})$ were extracted with $5 \mathrm{ml}$ of $80 \%$ ethanol, by boiling the samples in glass tubes in a $95^{\circ} \mathrm{C}$-water bath for $10 \mathrm{~min}$. After extraction, the tubes were centrifuged at $489 \times g$ for $5 \mathrm{~min}$, and the supernatants of the extractions were used for sugar analysis. One hundred $\mathrm{ml}$ of sample was added to $900 \mathrm{ml}$ of distilled water then mixture was vortexed. One $\mathrm{ml}$ of $5 \%$ phenol and $5 \mathrm{ml}$ of $\mathrm{H}_{2} \mathrm{SO}_{4}$ were added to $1 \mathrm{ml}$ of sample and the mixture was stirred. After cooling under room temperature for $15 \mathrm{~min}$, absorbance of sample was recorded at $490 \mathrm{~nm}$.

\section{Analysis of mineral ions}

Total ion content $\left(\mathrm{Na}^{+}, \mathrm{Ca}^{2+}, \mathrm{K}^{+}\right.$and $\left.\mathrm{Mg}^{2+}\right)$ was measured with a $\mathrm{pH} / \mathrm{mV} / \mathrm{Ion} / \mathrm{Temp}$ meter (JENCO $6251 \mathrm{~N}$ ). The leaf samples $(0.5 \mathrm{~g})$ were homogenized with liquid nitrogen in $5 \mathrm{ml}$ deionized water. The homogenate was boiled in a water bath for $10 \mathrm{~min}$. The precipitate was removed by centrifugation.

\section{Statistical analysis}

Analysis of variance (ANOVA) of means of 6 replicates for leaf water potential, RWC, dry weight, amounts of inorganic ions, proline, protein and total soluble sugar contents was performed with Duncan Multiple Comparison test using SPSS for Microsoft Windows (Ver. 10.0, SPSS Inc., USA) and statistical significance between the two cultivars along with different treatments was determined at $\mathrm{P}<0.05$ level. 


\section{Results}

\section{Copper content}

Copper concentrations were determined in the leaves of the test plants and shown in Figure 1. The plants that grown under $0.5 \mathrm{mM} \mathrm{Cu}$ revealed high $\mathrm{Cu}$ concentration. Exogenous $\mathrm{H}_{2} \mathrm{O}_{2}$ applications $\left(\mathrm{H}_{2} \mathrm{O}_{2}\right.$ group and $\mathrm{Cu}$ $+\mathrm{H}_{2} \mathrm{O}_{2}$ group) also caused the increases in the copper content of the leaves of both cultivars. However, the increases in Akpinar cv. were higher than Pegaso cv. ones in both $\mathrm{H}_{2} \mathrm{O}_{2}$ group and $\mathrm{Cu}+\mathrm{H}_{2} \mathrm{O}_{2}$ group. For instance, in Pegaso cv., $\mathrm{Cu}$ concentrations were measured as $26 \pm$ 3 , and $29 \pm 0.4 \mu \mathrm{g} \mathrm{g}^{-1}$ dry weight in the control and $\mathrm{H}_{2} \mathrm{O}_{2}$-treated group, respectively. Under excess $\mathrm{Cu}$ applications, $\mathrm{Cu}$ concentrations were recorded as $45 \pm 0.3$ and $49 \pm 0.4 \mu \mathrm{g} \mathrm{g}^{-1}$ dry weight in the copper exposed plants and copper stress plus $\mathrm{H}_{2} \mathrm{O}_{2}$ pretreated plants, respectively. As for Akpinar cv., $\mathrm{Cu}$ concentrations were found as $27 \pm 2$, and $32 \pm 2 \mu \mathrm{g} \mathrm{g}^{-1}$ dry weight in the control and $\mathrm{H}_{2} \mathrm{O}_{2}$-treated group, respectively. Also, under excess $\mathrm{Cu}$ applications, the concentrations were recorded as $39 \pm 2$ and $51 \pm 2 \mu \mathrm{g} \mathrm{g}{ }^{-1}$ dry weight in the $\mathrm{Cu}$ group and $\mathrm{Cu}+\mathrm{H}_{2} \mathrm{O}_{2}$ group, respectively (Figure 1).

\section{$\mathrm{H}_{2} \mathrm{O}_{2}$ content}

Endogenic $\mathrm{H}_{2} \mathrm{O}_{2}$ content after exogenous applications increased in two cultivars. Also, the $\mathrm{H}_{2} \mathrm{O}_{2}$ concentration significantly increased under excess copper. Pretreatment with $\mathrm{H}_{2} \mathrm{O}_{2}$ also reduced the overproduction of $\mathrm{H}_{2} \mathrm{O}_{2}$ in both cultivars under copper stress (Figure 2).

\section{Plant growth}

Toxicity of copper and the effect of $\mathrm{H}_{2} \mathrm{O}_{2}$ application on the growth of maize cultivars, Akpinar and Pegaso are presented in Figure 3. To understand how $\mathrm{H}_{2} \mathrm{O}_{2}$ induced tolerance to copper stress, we studied the changes in dry matter and mineral ion content, and osmoregulation mechanism of the leaves of two maize cultivars. While maize cultivars exposure to excess $\mathrm{Cu}$ showed a significant decrease in dry matter, dry weights of $\mathrm{H}_{2} \mathrm{O}_{2}$-treated plants revealed a significant increase. $\mathrm{H}_{2} \mathrm{O}_{2}$ pretreatment also reduced the decrease in amount of dry matter in both cultivars (Figure $3 \mathrm{~A}$ ).

A protocol used for phytotoxicity testing, the grade of growth inhibition (\%) was also evaluated in this study and a significant GGI (\%) was observed in plants treated with $0.5 \mathrm{mM} \mathrm{Cu}$. However, the copper-induced growth inhibition decreased when the seedlings were pretreated with $\mathrm{H}_{2} \mathrm{O}_{2}$. GGI values were recorded as $-9 \%$ (negative value represents the increase in growth), $24 \%$, and $10 \%$ in $\mathrm{H}_{2} \mathrm{O}_{2}$ group, $\mathrm{Cu}$ group and $\mathrm{Cu}+\mathrm{H}_{2} \mathrm{O}_{2}$ group of Akpinar cultivar, respectively. As for Pegaso, the values were found as $-14 \%, 31 \%$ and $18 \%$ in $\mathrm{H}_{2} \mathrm{O}_{2}$ group, $\mathrm{Cu}$ group and $\mathrm{Cu}+\mathrm{H}_{2} \mathrm{O}_{2}$ group, respectively (Figure $3 \mathrm{~B}$ ).

\section{Water status}

In general, decrease in leaf water potential or RWC in plants is considered as direct indicator of the stress. $\Psi_{\text {leaf }}$ and RWCs of both maize cultivars statistically decreased in copper stress applied plants compared to control plants. On the contrary, pretreatment of $\mathrm{H}_{2} \mathrm{O}_{2} \quad\left(\mathrm{Cu}+\mathrm{H}_{2} \mathrm{O}_{2}\right.$ group) prevented the decrease in leaf water potential and RWC values. $\mathrm{H}_{2} \mathrm{O}_{2}$ treatment also increased leaf water potential and RWC in both Pegaso and Akpinar cultivars. For instance, while in control plants of Pegaso, $\Psi_{\text {leaf }}$ was found as $-0.84 \mathrm{MPa}$, the value was $-1.27 \mathrm{MPa}$ in copper stress exposed plants. As mentioned, $\mathrm{H}_{2} \mathrm{O}_{2}$ treatments increased the values of $\Psi_{\text {leaf }}$. The values of $\Psi l_{\text {eaf }}$ were determined as $-0.64 \mathrm{MPa}$ and $-1.06 \mathrm{MPa}$ in $\mathrm{H}_{2} \mathrm{O}_{2}$ treated plants and copper stress plus $\mathrm{H}_{2} \mathrm{O}_{2}$ pretreated plants, respectively. Similarly, in control plants of Pegaso cultivar, the value of RWC was measured as 95\%. The value was $92.6 \%$ under excess copper. However, RWC values were estimated as $97.4 \%$ and $93.8 \%$, in $\mathrm{H}_{2} \mathrm{O}_{2}$ treated plants and copper stress plus $\mathrm{H}_{2} \mathrm{O}_{2}$ pretreated plants, respectively. A

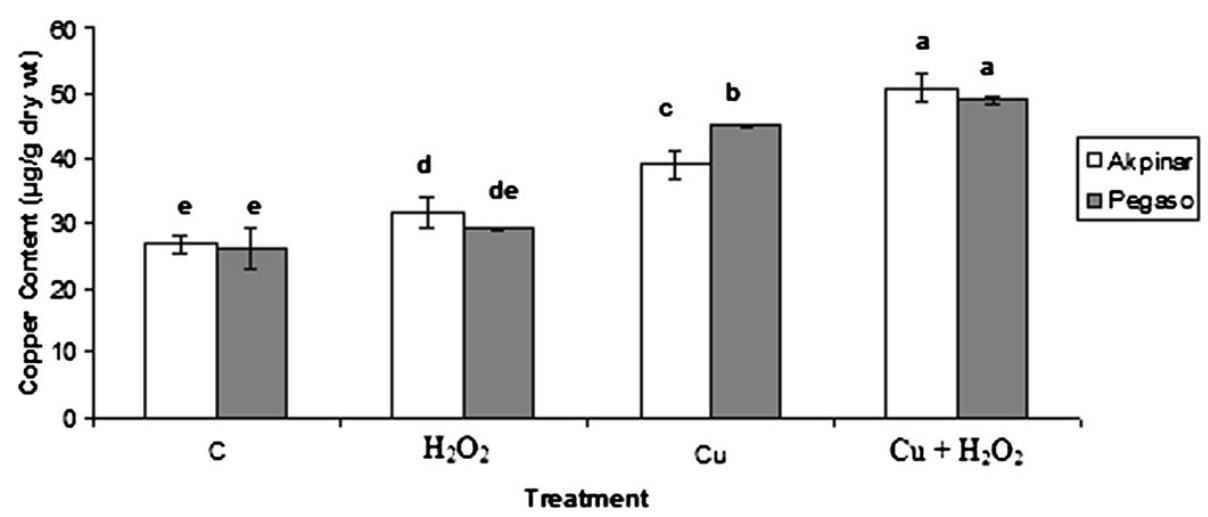

Figure 1 The effect of $\mathrm{H}_{2} \mathrm{O}_{2}$ application on $\mathrm{Cu}$ concentration under excess copper in maize cultivars. The plants were submitted to four treatments: control (C); $\mathrm{H}_{2} \mathrm{O}_{2}$ treatment $\left(\mathrm{H}_{2} \mathrm{O}_{2}\right)$; Cu stressed $(\mathrm{Cu}) ; \mathrm{Cu}$ stressed plus $\mathrm{H}_{2} \mathrm{O}_{2}$ pretreatment $\left(\mathrm{Cu}+\mathrm{H}_{2} \mathrm{O}_{2}\right)$. Vertical bars represent standard deviation. Different letters denote significant differences between the two cultivars along with different treatments at $p<0.05$. 


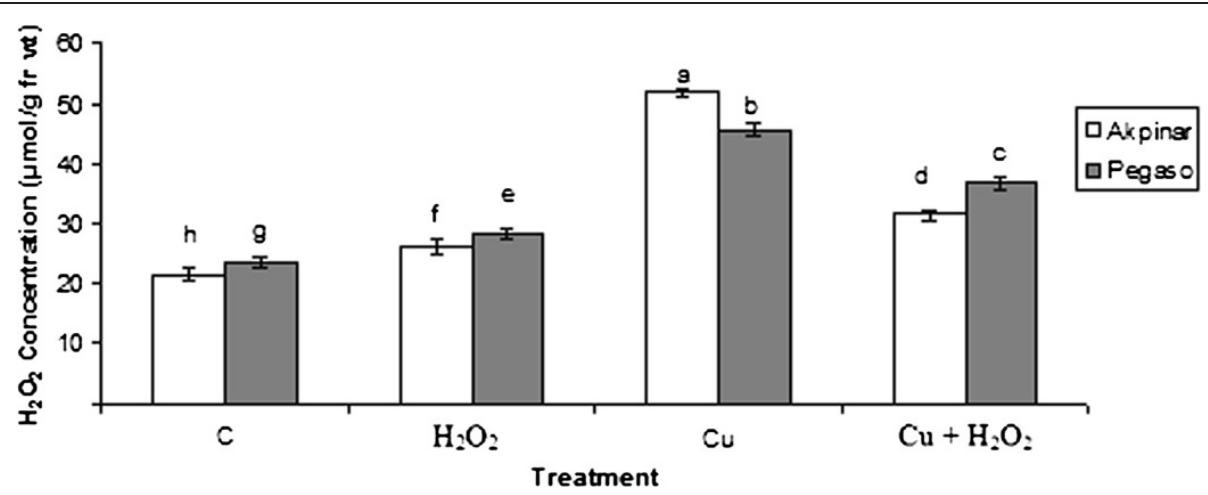

Figure 2 The effect of $\mathrm{H}_{2} \mathrm{O}_{2}$ application on $\mathrm{H}_{2} \mathrm{O}_{2}$ content under excess copper in maize cultivars. Vertical bars represent standard deviation. Different letters denote significant differences between the two cultivars along with different treatments at $p<0.05$.

similar trend of the $\Psi_{\text {leaf }}$ and RWC was also recorded in Akpinar cultivar (Figure 4).

\section{Proline content}

The proline content of the maize cultivars exposed to $\mathrm{Cu}$ or/and $\mathrm{H}_{2} \mathrm{O}_{2}$ exhibited a specific increase. Exposure to either copper or $\mathrm{H}_{2} \mathrm{O}_{2}$ resulted in a rise in proline level of test plants. Interestingly, in unstressed plants, treatment of $\mathrm{H}_{2} \mathrm{O}_{2}$ also increased the proline level. The proline accumulation was of the greatest magnitude in copper stress plus $\mathrm{H}_{2} \mathrm{O}_{2}$ pretreatment $\left(\mathrm{Cu}+\mathrm{H}_{2} \mathrm{O}_{2}\right)$ (Figure 5).

\section{Soluble protein content}

The results of Figure 6 showed that soluble protein contents of Pegaso and Akpinar cultivars decreased in plants exposed to excess copper, however, $\mathrm{H}_{2} \mathrm{O}_{2}$ applications prevented the decrease in soluble protein content. Moreover, treatment with $\mathrm{H}_{2} \mathrm{O}_{2}$ alone increased the

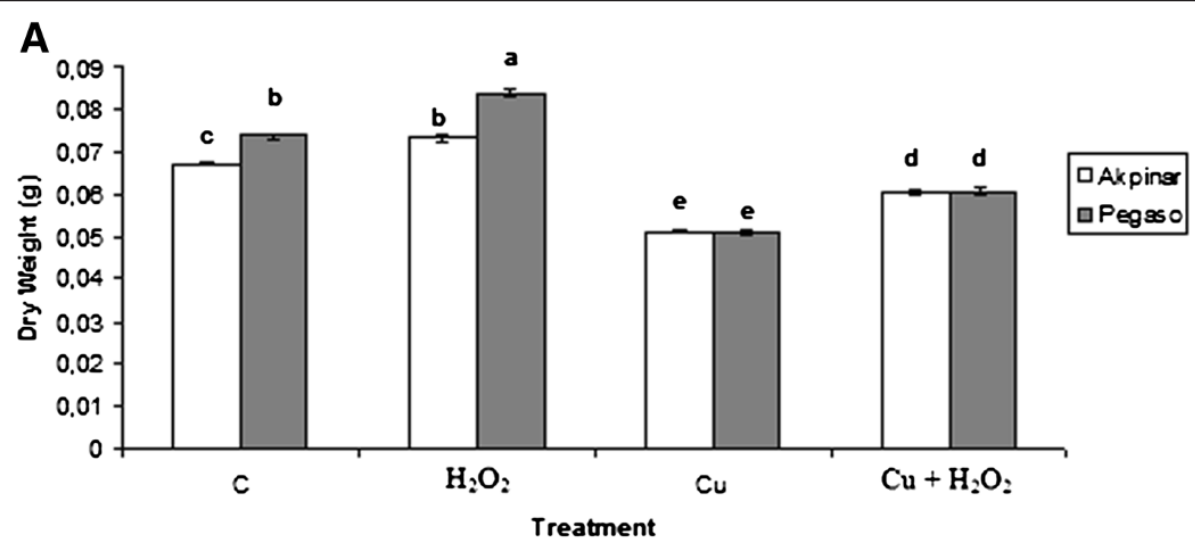

B

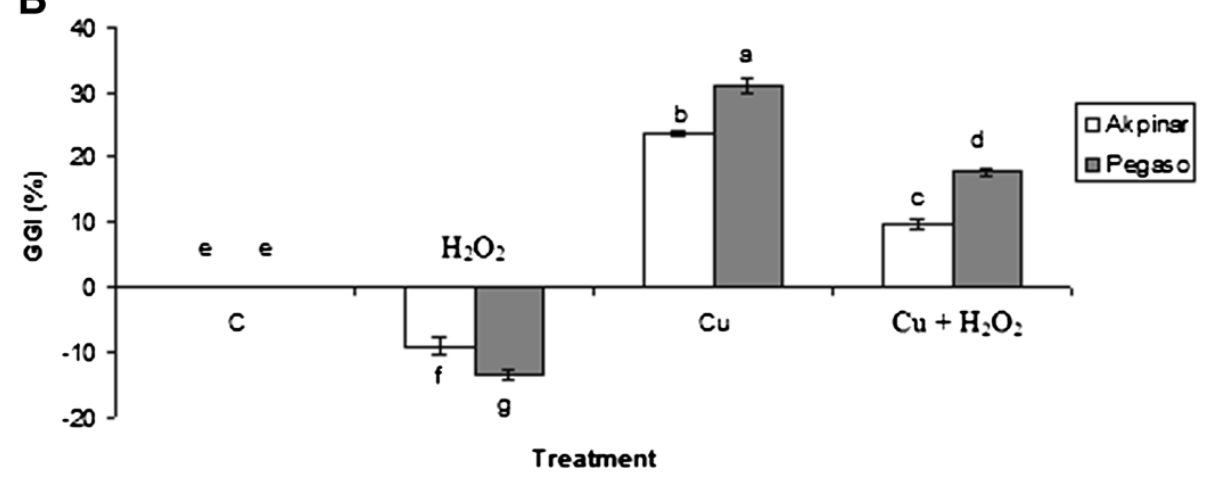

Figure 3 The effect of $\mathrm{H}_{2} \mathrm{O}_{2}$ application on dry weight and GGI (\%) under excess copper in maize cultivars. A and $\mathrm{B}$ represent dry weight and $\mathrm{GGI}(\%)$, respectively. Vertical bars represent standard deviation. Different letters denote significant differences between the two cultivars along with different treatments at $p<0.05$. 


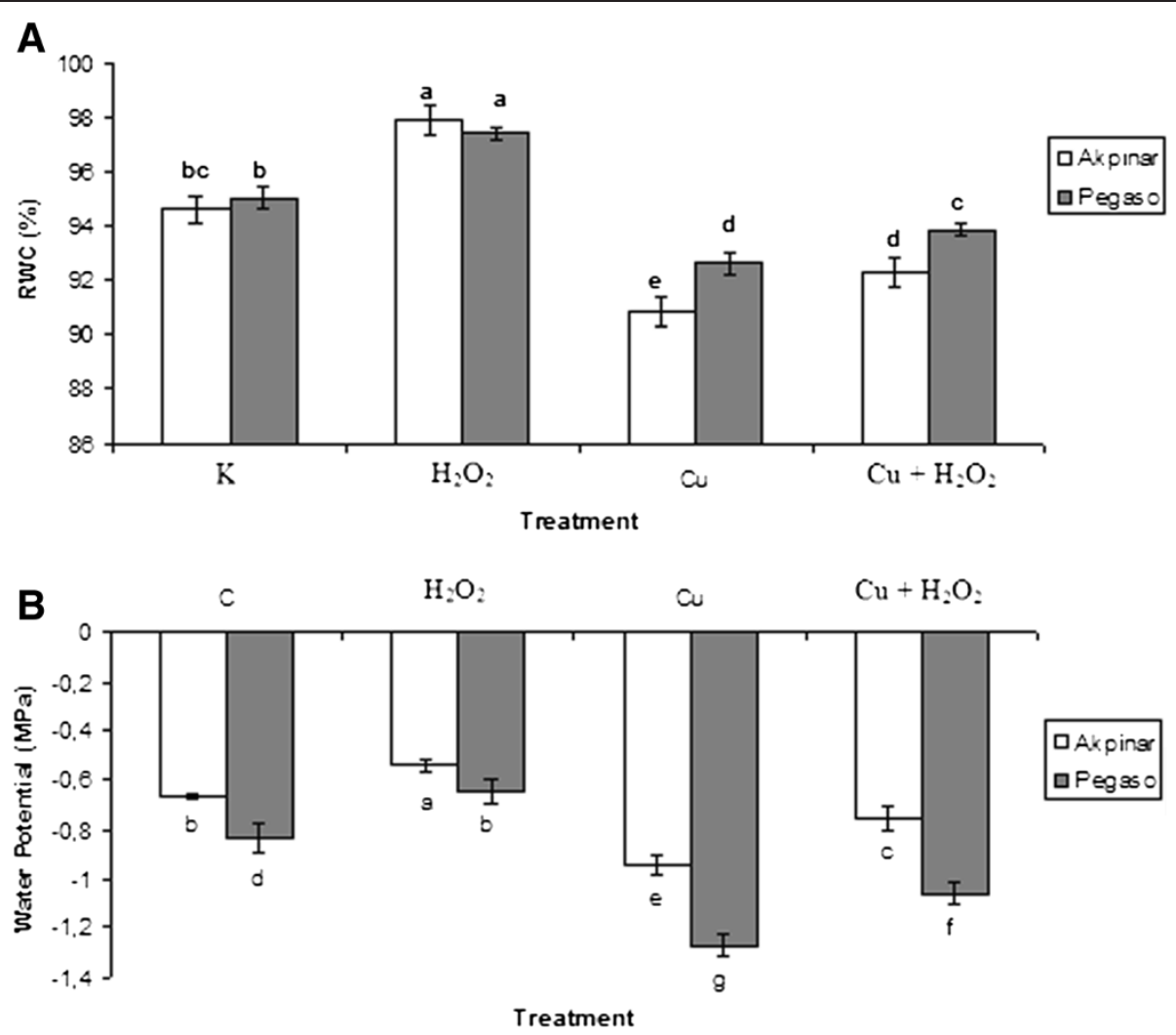

Figure 4 The effect of $\mathrm{H}_{2} \mathrm{O}_{2}$ application on leaf water status under excess copper in maize cultivars. A and $\mathrm{B}$ represent relative water content (RWC) and leaf water potential $\left(\Psi_{\text {leaf }}\right)$, respectively. Vertical bars represent standard deviation. Different letters denote significant differences between the two cultivars along with different treatments at $p<0.05$.

protein content in both cultivars. Similarly, protein content increased in the copper stress plus $\mathrm{H}_{2} \mathrm{O}_{2}$ pretreatment $\left(\mathrm{Cu}+\mathrm{H}_{2} \mathrm{O}_{2}\right)$ compared to control group.

\section{Total soluble sugars}

The total soluble sugar contents of the control plants were measured as $53 \pm 0.004 \mu \mathrm{g}$ and $79 \pm 0.001 \mu \mathrm{g}$ per $\mathrm{g}$ dry weight in Akpinar and Pegaso cultivars, respectively.
After treatment with $\mathrm{H}_{2} \mathrm{O}_{2}\left(\mathrm{H}_{2} \mathrm{O}_{2}\right.$ group), total soluble sugar contents in the leaves were elevated in both cultivars. The $\mathrm{Cu}$ exposure ( $\mathrm{Cu}$ group) also increased the total soluble sugar content significantly in the leaves of maize cultivars compared to the control group. The soluble sugar content showed a higher increase under pretreatment of $\mathrm{H}_{2} \mathrm{O}_{2}\left(\mathrm{Cu}+\mathrm{H}_{2} \mathrm{O}_{2}\right.$ group) than under $\mathrm{Cu}$ stress (Figure 7).

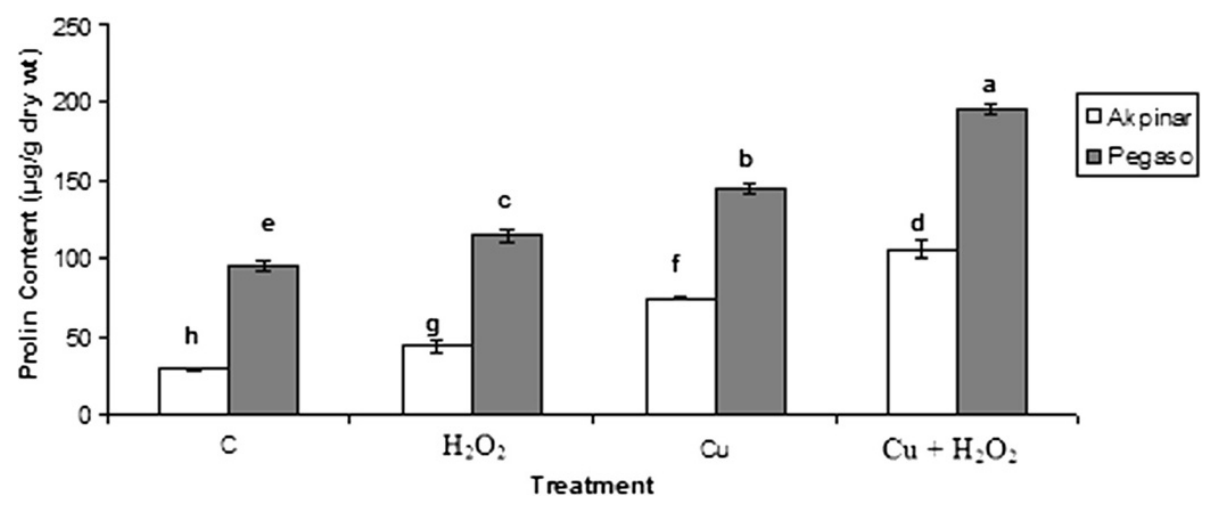

Figure 5 The effect of $\mathrm{H}_{2} \mathrm{O}_{2}$ application on proline content under excess copper in maize cultivars. Vertical bars represent standard deviation. Different letters denote significant differences between the two cultivars along with different treatments at $p<0.05$. 


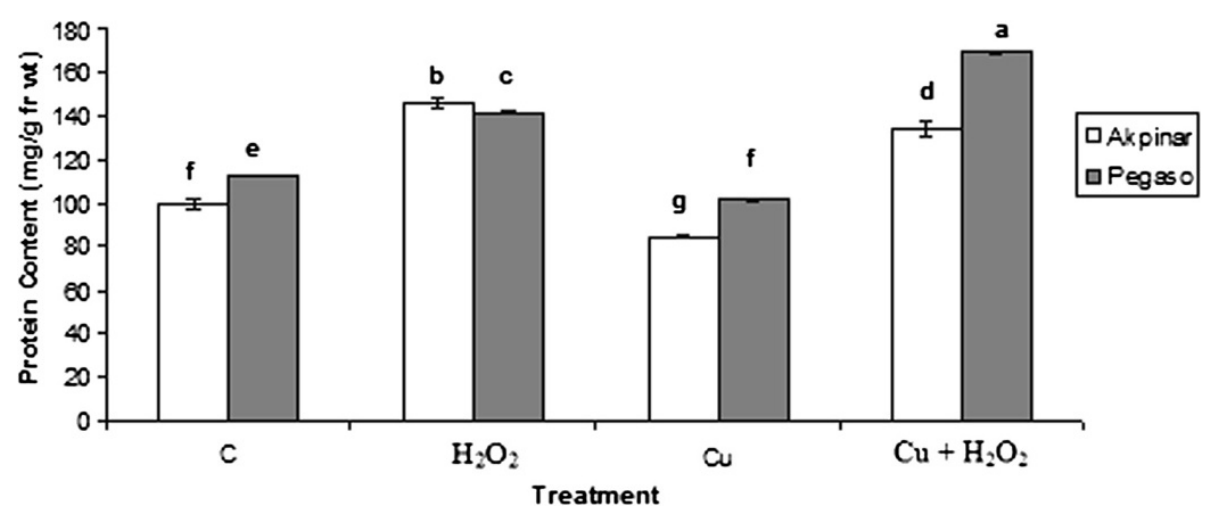

Figure 6 The effect of $\mathrm{H}_{2} \mathrm{O}_{2}$ application on soluble protein content under excess copper in maize cultivars. Vertical bars represent standard deviation. Different letters denote significant differences between the two cultivars along with different treatments at $p<0.05$.

\section{Inorganic ion concentrations}

In Figure 8 the results for ion concentration of the leaves have been presented, for these elements where significant changes were detected. Ion concentrations $\left(\mathrm{Na}^{+}\right.$, $\mathrm{Ca}^{2+}, \mathrm{K}^{+}$and $\mathrm{Mg}^{2+}$ ) of the leaves of maize cultivars showed that the content of these ions was decreased by excess copper ( $\mathrm{Cu}$ group) but increased by $\mathrm{H}_{2} \mathrm{O}_{2}$ treatment $\left(\mathrm{H}_{2} \mathrm{O}_{2}\right.$ group). Mineral ion concentration of the $\mathrm{H}_{2} \mathrm{O}_{2}$-treated maize cultivars was the highest. When $\mathrm{H}_{2} \mathrm{O}_{2}$ pretreatment was combined with the excess $\mathrm{Cu}$ $\left(\mathrm{Cu}+\mathrm{H}_{2} \mathrm{O}_{2}\right.$ group), the decrease in the content of these ions was prevented slightly.

\section{Discussion}

In recent years, it has been reported that $\mathrm{H}_{2} \mathrm{O}_{2}$ pretreatment alleviates the damages of the some abiotic stresses such as salt stress in wheat seedlings (Li et al., 2011), oxidative stress in young pea leaves (Moskova et al., 2009), heat stress in cucumber leaves (Gao et al., 2010), aluminum-induced oxidative stress in wheat seedlings (Xu et al., 2011) and cadmium stress in rice seedlings ( $\mathrm{Hu}$ et al., 2009). However, the exact mechanism of the protective action of $\mathrm{H}_{2} \mathrm{O}_{2}$ application at low concentrations against various stresses especially copper stress is not yet elucidated. In the present study, we investigated whether exogenous $\mathrm{H}_{2} \mathrm{O}_{2}$ could protect the growth and water content under excess copper and whether the protective effect was associated with the nutrient concentration and osmotic regulation in the leaf tissues. We determined that treatment of maize cultivars with excess copper resulted in a sharply decrease in dry matter of the leaves but exogenous $\mathrm{H}_{2} \mathrm{O}_{2}$ applications improved the amount of dry matter. Similar to our data, Mocquot et al. (1996), reported a significant decrease in root and leaf biomass of 14-days old maize leaves at $10 \mu \mathrm{M} \mathrm{Cu}$ concentration. Khandaker et al. (2012), also recorded that exogenous $\mathrm{H}_{2} \mathrm{O}_{2}$ increased photosynthetic rates and dry matter content of the leaves in wax apple under field conditions. Collectively, the dry matter enhancement by exogenous application of $\mathrm{H}_{2} \mathrm{O}_{2}$ may be of tremendous agricultural importance especially in copper contaminated area. We also observed that exogenous $\mathrm{H}_{2} \mathrm{O}_{2}$ prevented the grade of growth inhibition in maize cultivars under excess copper. Our findings suggested that $\mathrm{H}_{2} \mathrm{O}_{2}$ application alleviated the hazardous effect of the copper metals on the plant growth. Accordingly, De Azevedo Neto et al. (2005),

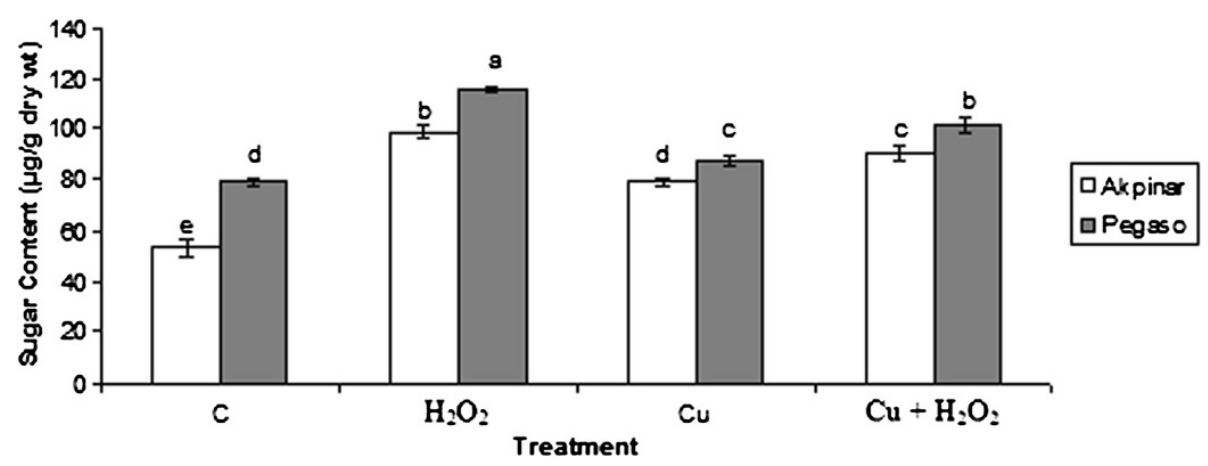

Figure 7 The effect of $\mathrm{H}_{2} \mathrm{O}_{2}$ application on total soluble sugar under excess copper in maize cultivars. Vertical bars represent standard deviation. Different letters denote significant differences between the two cultivars along with different treatments at $p<0.05$. 

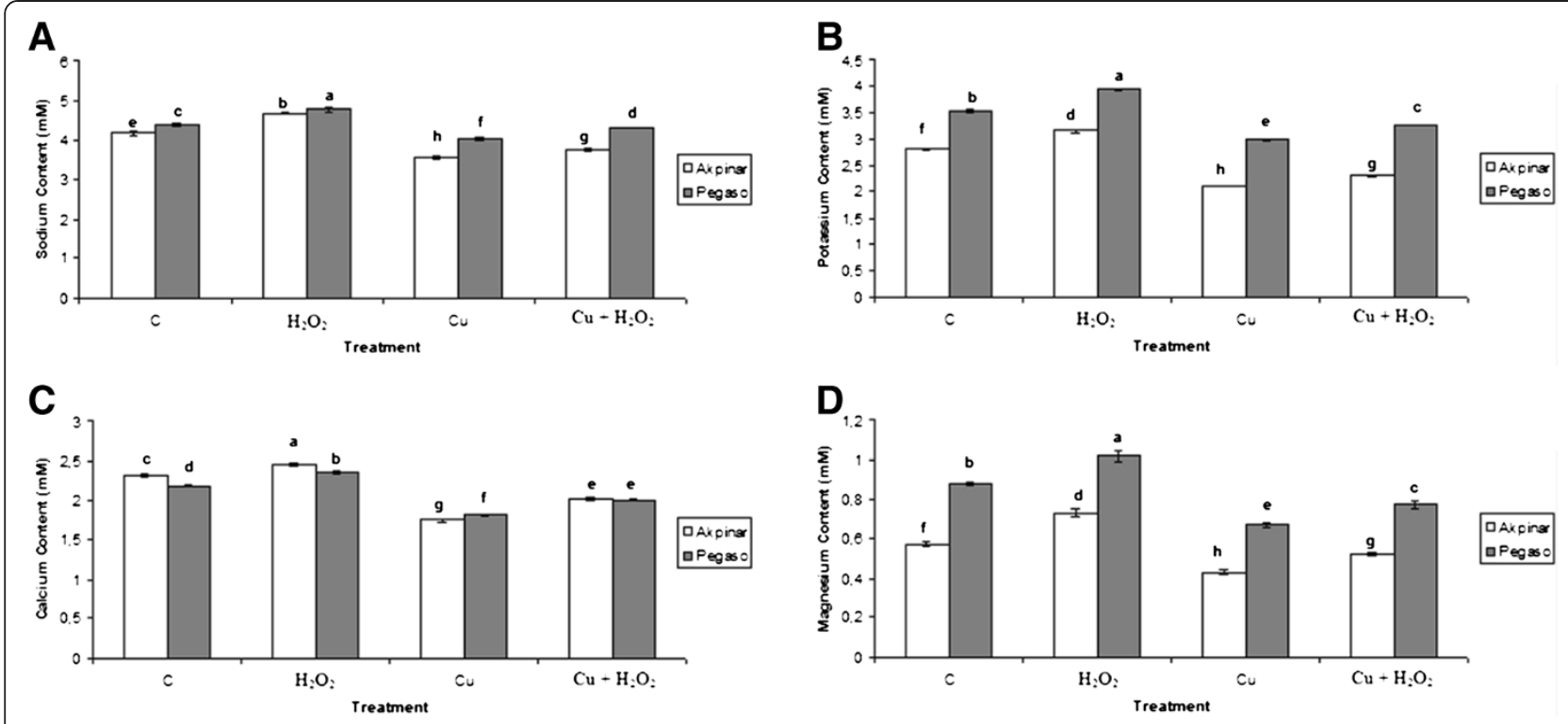

Figure 8 The effect of $\mathrm{H}_{2} \mathrm{O}_{2}$ application on inorganic ions under excess copper in maize cultivars. A: Sodium content, B: Potassium content, C: Calcium content, D: Magnesium content. Vertical bars represent standard deviation. Different letters denote significant differences between the two cultivars along with different treatments at $p<0.05$.

observed that salt-induced growth inhibition decreased when the seedlings were pretreated with $\mathrm{H}_{2} \mathrm{O}_{2}$.

Exposure to heavy metals including $\mathrm{Cu}$ is known to deteriorate the plant water balance. The present investigation also showed that pretreatment of $\mathrm{H}_{2} \mathrm{O}_{2}$ protected the water content of the maize leaves under copper stress. Similar to our results, Wahid et al. (2007), reported that $\mathrm{H}_{2} \mathrm{O}_{2}$ treatment improved leaf water relations of salinity-treated wheat seedlings by turgor maintenance. Liao et al. (2012) also proposed that $\mathrm{H}_{2} \mathrm{O}_{2}$ in vase solution of cut flowers reduced the decline in leaf relative water content.

In the present study, it was also researched the changes in substances involved in osmotic regulation such as proline, soluble protein, total sugar and some mineral ions. As known, the proteinogenic amino acid proline functions as an osmolyte, radical scavenger, electron sink, stabilizer of macromolecules, and a cell wall component (Aspinall and Paleg, 1981). Proline accumulation as a function of excess metal was observed in Pegaso and Akpinar cultivars. The increased proline content in maize cultivars exposed to copper stress may be associated with the response to water deficit. Indeed, excess $\mathrm{Cu}$-induced accumulation of proline has been recorded in various plants such as Oryza sativa (Chen et al., 2001) and Nicotiana benthamiana ( $\mathrm{Ku}$ et al., 2012). We also observed that proline accumulation was high in the plants treated with $\mathrm{H}_{2} \mathrm{O}_{2}$ in two maize cultivars. Based on its known properties, the increases in $\mathrm{H}_{2} \mathrm{O}_{2}$-treated groups may be ascribed in scavenging of free radicals. In copper stress plus $\mathrm{H}_{2} \mathrm{O}_{2}$ pretreated plants, the increases in proline content also may be attribute to its a variety of functions e.g. osmo-regulation, redox-regulation and metal chelation. Similar to our data, Yang et al. (2009), recorded that exogenous $\mathrm{H}_{2} \mathrm{O}_{2}$ treatment led to a significant accumulation of proline in coleoptiles and radicles of maize seedlings.

One of the causes of proline accumulation in plant tissues has been suggested to be hydrolysis of proteins (Aspinall and Paleg, 1981). In the present study, it was actually observed that soluble protein content decreased in the $\mathrm{Cu}$ group plants while increasing proline content. Under biotic and abiotic stress factors causing a reduction of growth, protein synthesis is one of the most negatively affected anabolic processes together with photosynthesis, transport of metabolites, and uptake and translocation of mineral ions (Bonjoch and Tamayo, 2003). On the other hand, it is known that copper ions can readily oxidize the thiol bonds present in the proteins, causing disruption of their structure and functions (Mouratao et al., 2009). Similar to our data, Yadav and Mohanpuria (2009), recorded that protein content decreased after exposure to $\mathrm{Cu}$ in the young leaves of two Camellia sinensis cultivars. On the other hand, we found that the copper-induced the loss of soluble protein disappeared when the seedlings were pretreated with $\mathrm{H}_{2} \mathrm{O}_{2}$ and moreover, the soluble protein content increased in both maize cultivars compared to the control group. The increased protein content could be due to a maintaining of the structure of proteins and/or could be due to an increased protein synthesis.

As known, sugar accumulation contributes for regulation of internal osmolarity and protection to the biomolecules 
and membranes (Sinniah et al., 1998). Effect of copper on the total soluble sugar contents of maize cultivars has been presented in Figure 7. These data indicated that excess copper increased the total soluble sugar content in both cultivars. Likewise, sucrose content, one of soluble sugars, enhanced in the cucumber leaves under copper stress (Alaoui-Sosse et al., 2004). We also observed that $\mathrm{H}_{2} \mathrm{O}_{2}$ pretreatment increased the total soluble sugar content in both maize cultivars. In line with these findings, exogenous $\mathrm{H}_{2} \mathrm{O}_{2}$ applications might protect the water status of the tissues by providing osmotic regulation.

We also researched the changes in ion concentrations involved in osmotic adjustment in two maize cultivars under $\mathrm{Cu}$ stress. As known, inorganic ions for osmotic adjustment are mainly sodium, calcium, potassium and chlorine (Chen and Jiang, 2010). Our findings showed that $\mathrm{Na}^{+}, \mathrm{Ca}^{2+}, \mathrm{K}^{+}$and $\mathrm{Mg}^{2+}$ concentrations decreased significantly in $\mathrm{Cu}$-stressed maize cultivars. Accordingly, it was reported a highly significant decreases in $\mathrm{Na}^{+}, \mathrm{Ca}^{2+}, \mathrm{K}^{+}$ and $\mathrm{Mg}^{2+}$ contents under excess copper (Ouzounidou et al., 1998; Alaoui-Sosse et al., 2004). The decline in $\mathrm{K}^{+}$ concentration may have played an important role in the inhibition of the growth. Similarly, Alaoui-Sosse et al. (2004), reported that the decrease in $\mathrm{K}^{+}$content may have played a crucial role in the inhibition of leaf expansion. In the same way, a decrease of $\mathrm{K}^{+}$content was observed in rice roots in response to extreme $\mathrm{Cu}$ exposure (Chen et al., 2004). As mentioned above, $\mathrm{Mg}^{2+}$ concentration decreased as a response to excess copper in both maize cultivars. The reduction in $\mathrm{Mg}^{2+}$ concentration may be attributed to the decrease in dry matter of the leaves. Indeed, it was reported that decline of $\mathrm{Mg}^{2+}$ concentration could contribute to the reduction in net assimilation rate and to accumulation of assimilates in leaves (Alaoui-Sosse et al., 2004). On the other hand, exogenous $\mathrm{H}_{2} \mathrm{O}_{2}$ applications improved the ion concentrations in both cultivars. According to our results, Wahid et al. (2007), reported that $\mathrm{H}_{2} \mathrm{O}_{2}$-treated wheat seedlings displayed greater tissue $\mathrm{Ca}^{2+}$ and $\mathrm{K}^{+}$levels under salt stress. These findings showed that the distribution of the ions could be affected by copper stress but $\mathrm{H}_{2} \mathrm{O}_{2}$ applications might maintain the mineral balance under the stress in maize seedlings. Furthermore, the increases in ion concentrations could be concerned to osmoregulation mechanism.

Maize cultivars exposed to excess $\mathrm{Cu}$ accumulated substantial amounts of $\mathrm{Cu}$ in their leaves. Exogenous $\mathrm{H}_{2} \mathrm{O}_{2}$ applications also caused the increases in the copper content in both cultivars. The increases make us thinking about that the $\mathrm{H}_{2} \mathrm{O}_{2}$ applications may affect the metal uptake proteins. Indeed, in recent years, it has been recorded that sustained low level of $\mathrm{H}_{2} \mathrm{O}_{2}$ application to cultured cells lead to up-regulation of the major iron uptake protein and thus induced iron uptake (Andriopoulos et al., 2007).
Similar to finding from $\mathrm{H}_{2} \mathrm{O}_{2}$ content studies (e.g. Xu et al., 2011), the present study also showed that $\mathrm{H}_{2} \mathrm{O}_{2}$ contents increased after each treatment in two maize cultivars. $\mathrm{H}_{2} \mathrm{O}_{2}$ is a strong oxidizing agent that injures cells and damages photosynthesis at high concentration when produced internally or applied externally (Wahid et al., 2007). However, $\mathrm{H}_{2} \mathrm{O}_{2}$ pretreatment in sublethal doses can exert a protective effect against copper stress by increasing the levels of osmotic solutes such as ion, proline, soluble protein and sugars in maize cultivars.

\section{Conclusion}

In conclusion, excess copper could inhibit the dry matter production, leaf water content, soluble protein level and mineral ion concentration such as potassium content, an important ion for osmotic regulation, and magnesium content required for photosynthesis, however, pretreatment of $\mathrm{H}_{2} \mathrm{O}_{2}$ could alleviate the hazardous effects of the copper stress. The results indicated that increased proline content and higher level of total soluble sugars might also participate in the alleviation of toxic effect of $\mathrm{Cu}$ accumulation. In other words, the changes induced by exogenous $\mathrm{H}_{2} \mathrm{O}_{2}$ in maize metabolism with osmotic adjustment under $\mathrm{Cu}$ stress may be involved in the defense of heavy metal. $\mathrm{H}_{2} \mathrm{O}_{2}$ pretreatment might affect the mineral ion distribution including copper in maize seedlings and thus contribute to decreasing of the deleterious effects of copper stress on the growth of maize.

\section{Competing interests}

The authors declare that they have no competing interest.

\section{Authors' contributions}

SG responsible for growth of the plants, stress applications, sampling, physiological and biochemical analysis and data analysis. RT conceived of the study, designed the experiment, supply all laboratory and chemical substances used in this study and also drafted the manuscript. Both authors read and approved the final manuscript.

\section{Acknowledgements}

The authors sincerely thank Dr. Duygu OZDES for technical support in copper analyzes.

\section{Author details}

${ }^{1}$ Department of Biology, Faculty of Arts and Sciences, Recep Tayyip Erdoğan University, Rize 53100, Turkey. ${ }^{2}$ Department of Biology, Faculty of Sciences, Karadeniz Technical University, Trabzon 61080, Turkey.

Received: 11 May 2012 Accepted: 3 October 2012

Published: 30 August 2013

\section{References}

Ahsan N, Lee DG, Lee SH, Kang KY, Lee JJ, Kim PJ, Yoon HS, Kim JS, Lee BH (2007) Excess copper induced physiological and proteomic changes in germinating rice seeds. Chemosphere 67:1182-1193

Alaoui-Sosse B, Genet P, Vinit-Dunand F, Toussaint ML, Epron D, Badot PM (2004) Effect of copper on growth in cucumber plants (Cucumis sativus) and its relationships with carbohydrate accumulation and changes in ion contents. Plant Sci 166:1213-1218

Alloway BJ (ed) (1990) Heavy Metals in Soils. John Wiley, New York

Andriopoulos B, Hegedüsch S, Margin J, Riedel HD, Hebling U, Wang J,

Pantopoulos K, Mueller S (2007) Sustained hydrogen peroxide induces iron 
uptake by transferrin receptor-1 independent of the iron regulatory protein/ iron-responsive element network. J Biol Chem 282:20301-20308

Ashraf M (2004) Some important physiological selection criteria for salt stress tolerance in plants. Flora 199:361-376

Aspinall D, Paleg LG (1981) Proline accumulation: physiological aspects. In: Paleg LG, Aspinall D (eds) The Physiology and Biochemistry of Drought Resistance in Plants. Academic Press, Australia, pp 205-240

Bates LS, Waldren RP, Teare ID (1973) Rapid determination of free proline for water stress studies. Plant Soil 39:205-207

Bonjoch NP, Tamayo PR (2003) Protein content quantification by Bradford method. In: Roger MJR (ed) Handbook Plant Ecophysiology Techiques. Kluwer Academic Publishers, Dordrecht, pp 283-295

Bradford MM (1976) A rapid and sensitive method for the quantitation of microgram quantities protein utilizing the principle of protein-dye binding. Anal Biochem 72:248-254

Castillo FJ (1996) Antioxidative protection in the inducible CAM plant Sedum album L. following the imposition of severe water stress and recovery. Oecologia 107:469-477

Chen H, Jiang JG (2010) Osmotic Adjustment and plant adaptation to environmental changes related to drought and salinity. Environ Rev 18:309-319

Chen CT, Chen LM, Lin CC, Kao CH (2001) Regulation of proline accumulation in detached rice leaves exposed to excess copper. Plant Sci 160:283-290

Chen CT, Chen TH, Luo KF, Chiu CY (2004) Effects of proline on copper transport in rice seedlings under excess copper stress. Plant Sci 166:103-111

De Azevedo Neto AD, Prisco JT, Eneas-Filho J, Medeiros JVR, Gomes-Filho E (2005) Hydrogen peroxide pre-treatment induces salt-stress acclimation in maize plants. J Plant Physiol 162:1114-1122

Dubois M, Gilles KA, Hamilton JK, Rebers PA, Smith F (1956) Colorimetric method for determination of sugars and related substances. Anal Chem 28:350-356

Foy CD, Chaney RL, White MC (1978) The physiology of metal toxicity in plants. Ann Rev Plant Physiol 29:511-566

Gao Y, Guo YK, Lin SH, Fang YY, Bai JG (2010) Hydrogen peroxide pretreatment alters the activity of antioxidant enzymes and protects chloroplast ultrastructure in heat-stressed cucumber leaves. Sci Hortic 126:20-26

Hu Y, Ge Y, Zhang C, Ju T, Cheng W (2009) Cadmium toxicity and translocation in rice seedlings are reduced by hydrogen peroxide pretreatment. Plant Growth Regul 59:51-61

Jiang LY, Yang XE, He ZL (2004) Growth response and phytoextraction of copper at different levels in soils by Elsholtzia splendens. Chemosphere 55:1179-1187

Khandaker MM, Boyce AN, Osman N (2012) The influence of hydrogen peroxide on the growth, development and quality of wax apple (Syzygium samarangense, [Blume] Merrill \& L.M. Perry var. jambu madu) fruits. Plant Physiol Bioch 53:101-110

Ku HM, Tan CW, Su YS, Chiu CY, Chen CT, Jan FJ (2012) The effect of water deficit and excess copper on proline metabolism in Nicotiana benthamiana. Biol Plant 56:337-343

Leita L, Nobili MD, Mondini C, Garcia MTB (1993) Response of Leguminosae to cadmium exposure. J Plant Nutr 16:200I-2012

Li JT, Qiu ZB, Zhang XW, Wang LS (2011) Exogenous hydrogen peroxide can enhance tolerance of wheat seedlings to salt stress. Acta Physiol Plant 33:835-842

Liao WB, Zhang ML, Huang GB, Yu JH (2012) Hydrogen peroxide in the vase solution increases vase life and keeping quality of cut Oriental x Trumpet hybrid lily 'Manissa'. Sci Hortic 139:32-38

Lin Q, Chen Y, Wang Z, Wang Y (2004) Study on the possibility of hydrogen peroxide pretreatment and plant system to remediate soil pollution. Chemosphere 57:1439-1447

Mocquot B, Vangronsveld J, Clijsters H, Mench M (1996) Copper toxicity in young maize (Zea mays L.) plants: effects on growth, mineral and chlorophyll contents, and enzyme activities. Plant Soil 182:287-300

Moskova I, Todorova D, Alexieva V, Ivanov S, Sergiev I (2009) Effect of exogenous hydrogen peroxide on enzymatic and nonenzymatic antioxidants in leaves of young pea plants treated with paraquat. Plant Growth Regul 57:193-202

Mouratao MP, Martins LL, Campos-Andrada MP (2009) Physiological responses of Lupinus luteus to different copper concentrations. Biol Plant 53:105-111

Ouzounidou G, Ilias I, Tranopoulou H, Karatalgis S (1998) Amelioration of copper toxicity by iron on spinach physiology. J Plant Nutr 21:2089-2101

Sinniah UR, Ellis RH, John P (1998) Irrigation and seed quality development in rapid-recycling Brassica: soluble carbohydrates and heat stable proteins. Ann Bot 82:647-655
Velikova V, Yordanov I, Edreva A (2000) Oxidative stress and some antioxidant systems in acid rain-treated bean plants. Protective role of exogenous polyamines. Plant Sci 151:59-66

Wahid A, Perveen M, Gelani S, Basra SMA (2007) Pretreatment of seed with $\mathrm{H}_{2} \mathrm{O}_{2}$ improves salt tolerance of wheat seedlings by alleviation of oxidative damage and expression of stress proteins. J Plant Physiol 164:283-294

Xu FJ, Jin CW, Liu WJ, Zhang YS, Lin XY (2011) Pretreatment with $\mathrm{H}_{2} \mathrm{O}_{2}$ alleviates aluminum-induced oxidative stress in wheat seedlings. J Integr Plant Biol 53:44-53

Yadav SK, Mohanpuria P (2009) Responses of Camellia sinensis cultivars to Cu and Al stress. Biol Plant 53:737-740

Yang SL, Lan SS, Gong M (2009) Hydrogen peroxide-induced proline and metabolic pathway of its accumulation in maize seedlings. J Plant Physiol 166:1694-1699

doi:10.1186/1999-3110-54-26

Cite this article as: Guzel and Terzi: Exogenous hydrogen peroxide increases dry matter production, mineral content and level of osmotic solutes in young maize leaves and alleviates deleterious effects of copper stress. Botanical Studies 2013 54:26.

\section{Submit your manuscript to a SpringerOpen ${ }^{\circ}$ journal and benefit from:}

- Convenient online submission

- Rigorous peer review

- Immediate publication on acceptance

- Open access: articles freely available online

- High visibility within the field

- Retaining the copyright to your article

Submit your next manuscript at $\gg$ springeropen.com 